\title{
Utilization of urine protein/creatinine ratio in pregnancy for diagnosis of preeclampsia
}

\author{
Nagajan Bhadarka ${ }^{1}$, Krutika Poddar ${ }^{1 *}$, Satyam Joshi $^{2}$
}

\begin{abstract}
${ }^{1}$ Department of Obstetrics and Gynecology, Gujarat Adani Institute of Medical Science, Bhuj, Kutch, Gujarat, India
${ }^{2}$ Pacific Dental College and Hospital, Udaipur, Rajasthan, India
\end{abstract}

Received: 26 June 2018

Accepted: 24 July 2018

\author{
*Correspondence: \\ Dr. Krutika Poddar, \\ E-mail: researchguide86@gmail.com
}

Copyright: () the author(s), publisher and licensee Medip Academy. This is an open-access article distributed under the terms of the Creative Commons Attribution Non-Commercial License, which permits unrestricted non-commercial use, distribution, and reproduction in any medium, provided the original work is properly cited.

\begin{abstract}
Background: The aim of the present study was to evaluate the ability of the random urine $\mathrm{P} / \mathrm{C}$ ratio to predict significant proteinuria, as well as to introduce a diagnostic test for preeclampsia that would avoid the inconvenience and time consumption of 24-hour urine protein collection.

Methods: A total of 100 women who were pregnant were included in the study. For urine test, the urine was collected for 24 hours. The women patients provided the mid stream urine sample prior to the collection period. Biuret colorimetric assay was used to determine the total protein in the urine and the creatinine concentration was measured with the help of modified Jaff test.

Results: The mean urinary protein excretion in 24 hour urine collection was found to be $2.05 \pm 0.74 \mathrm{~g} / \mathrm{dl}$ and the median serum creatinine concentration was found to be $0.82 \mathrm{mg} / \mathrm{dl}$. The mean $\mathrm{p} / \mathrm{c}$ ratio was found to be $1.94 \pm 0.83$. The correlation coefficient for the $\mathrm{p} / \mathrm{c}$ ratio against the 24 hour urine protein excretion was found to be 0.88 .

Conclusions: This test can also be used as a reasonable alternative to 24-hour urine protein excretion, especially in emergency situations, and, it could also complement the urinary dipstick test in preeclamptic pregnancy.
\end{abstract}

Keywords: Createnine, Preeclampsia, Protein, Urine

\section{INTRODUCTION}

When there is increase in the blood pressure along with extraction of protein in urine during pregnancy, the disorder is called as Pre-eclampsia. The condition is said to arise 20 weeks after pregnancy. ${ }^{1}$ In severe cases there may be swelling, kidney dysfunction, shortness of breath, breakdown of red blood cell and decrease in platelet count. Due to presence of such conditions there are chances of increase in risk to the baby and mother. After 20 weeks of period if the systolic blood pressure is more than $140 \mathrm{mmHg}$ and diastolic is more than $90 \mathrm{mmHg}$ when measured at the gap of four hours at two different times it is considered as positive high blood pressure. ${ }^{2}$ During prenatal care there is routine screen of Preeclampsia. If there is increase in the urine protein of 300 mg or more per 24 hour period it is called as proteinuria. The gold standard method of urine collection every 24 hours is the more time consuming test for the qualitative evaluation of the proteinuria induced by preeclampsia. There is the need of more rapid test which is capable of predicting the values of 24 hours accurately. Such type of test would be more valuable. The alternative and effective method to get the valuable result is the measurement of the protein-creatinine $(\mathrm{p} / \mathrm{c})$ ratio in urine sample. This is more convenient and rapid method to assess the protein excretion. ${ }^{3,4}$

The prevalence of the preeclampsia is around 2\%-8\% pregnant population. It is found to be the most common cause of death during pregnancy. Preeclampsia is found to be more common in the first pregnancy cases and if 
she carries twins. There are various risk factors for it which includes obesity, hypertension, gestational diabetes, old age and diabetes mellitus. The mechanism involves abnormal formation of blood vessels in the placenta. ${ }^{5,6}$

The ratio of the spot urine protein excretion to the creatinine excretion and can normalize the protein excretion to the glomerular filtration rate. Hence the random urine $\mathrm{p} / \mathrm{c}$ ratio is not influenced by variations in hydration status. ${ }^{7,8}$ The aim of the present study was to evaluate the ability of the random urine $\mathrm{P} / \mathrm{C}$ ratio to predict significant proteinuria, as well as to introduce a diagnostic test for preeclampsia that would avoid the inconvenience and time consumption of 24-hour urine protein collection.

\section{METHODS}

In the present study, pregnant women with the suspicious history of preeclampsia were included in our present study. All the pregnant women were admitted to the gynaecology department of the medical college. The exclusion criteria included: Known bacterial infection, presence of any kidney disease, presence of diabetes mellitus and bed rest for longer than 24 hours. In addition to the above mentioned criteria the women who delivered the babies at the day of the urine collection were also excluded from the study.

If the blood pressure was more than 140/90 $\mathrm{mm} \mathrm{Hg}$ after the period of 20th week of gestation than it was considered as Preeclampsia. The blood pressure is to be measured at the average of twice daily with the gap of 6 hours in between.

A total of 100 women who were pregnant were included in the study. All the women were seen to meet the inclusion criteria for the study. The women were explained about the study and the procedure they will have to undergo for the study and the written informed consent was signed from them. For urine test, the urine was collected for 24 hours. The women patients provided the mid-stream urine sample prior to the collection period. Biuret colorimetric assay was used to determine the total protein in the urine and the creatinine concentration was measured with the help of modified Jaff test. The cutoff point to diagnose the severe proteniuria was the use of result of 24 hour urine protein excretion. This standard was used to determine the specificity, sensitivity, negative and positive predictive value of the random urine $\mathrm{p} / \mathrm{c}$ ratio. $\mathrm{P}$ value less than 0.05 was considered significant.

\section{RESULTS}

A total of 100 pregnant women who meet the inclusion and exclusion criteria were included in the study. The mean age was found to be $22 \pm 3$ years (range 17 to 30 years). Their mean gestational age was found to be $35 \pm 4$ weeks (range 24 to 40 weeks) (Table 1). The mean urinary protein excretion in 24 hour urine collection was found to be $2.05 \pm 0.74 \mathrm{~g} / \mathrm{dl}$ and the median serum creatinine concentration was found to be $0.82 \mathrm{mg} / \mathrm{dl}$. The mean $\mathrm{p} / \mathrm{c}$ ratio was found to be $1.94 \pm 0.83$. The correlation coefficient for the $\mathrm{p} / \mathrm{c}$ ratio against the 24 hour urine protein excretion was found to be 0.88 . The positive and negative predictive vales for $\mathrm{p} / \mathrm{c}$ ratios 1.94 were $95 \%$ and $97 \%$ respectively. The sensitivity and the specificity were found to be $92 \%$ and $85 \%$ respectively.

Table 1: Demographic characteristics of the participants.

\begin{tabular}{|lll|}
\hline Variable & Mean & Standard deviation \\
\hline Age & 22 & 3 \\
\hline Gestational age & 35 & 4 \\
\hline
\end{tabular}

\section{DISCUSSION}

With the presence of the proteinuria in the body we can establish the diagnosis of preeclampsia, hence it has been considered as an indicator of the severity of the disease and the prognosis of the patients. Due to glomerular endotheliosis there is increased excretion of protein in urine. ${ }^{9,10}$

The major problem that is encountered with this method is that there is no defined abnormal level for the level of protein in the urine. The most common method used for the detection of proteinuria is the dipstick method of urine samples. ${ }^{11}$ With the help of dipstick there is rapid measurement of the test however it has low sensitivity and specificity. The 24 hour protein collection is considered to be gold standard method of detection of proteinuria, however it is not always correctly performed and can result in the delay in the diagnosis and inaccurate results too. ${ }^{12,13}$ As the result of which an alternative test of $\mathrm{p} / \mathrm{c}$ ratio was developed in the on spot urine sample in the pregnant women. It was found to have high accuracy and reproducibility and convenience as compared to 24 hour urine protein collection. According to the Morales et al the error in the $\mathrm{p} / \mathrm{c}$ ratio is less as compared to the error found in 24 hour urine samples.

In the present study, urine $\mathrm{p} / \mathrm{c}$ ratio was found to be 1.94 with the protein excretion rate of $300 \mathrm{mg} / 24 \mathrm{~h}$. The result was found to be consistent with the previous studies; we found a strong correlation between the p/c ratio and 24 hour urine protein. The correlation coefficient was found to be 0.88 . However, using the spot $\mathrm{P} / \mathrm{C}$ ratio of 0.88 as a correlate to the critical value of $300 \mathrm{mg}$ of protein over 24 hours would result in the failure to identify significant proteinuria in approximately $10 \%$ of affected patients. In an analysis by Cote et al, the spot $\mathrm{P} / \mathrm{C}$ ratio had a pooled sensitivity of $83.6 \%$ and specificity of $76.3 \%$ using a cut off of 0.26 to predict proteinuria $>300 \mathrm{mg} /$ day in a 24 hour collection, concluding that $\mathrm{P} / \mathrm{C}$ is a reasonable rule out test for excluding proteinuria.14 Keeping all this in mind the data suggest that urine $\mathrm{p} / \mathrm{c}$ ratio $>0.7$ strongly 
predicts siognificant proteinuria whereas in our study the ratio was found to be 1.94 .

\section{CONCLUSION}

This test can also be used as a reasonable alternative to 24-hour urine protein excretion, especially in emergency situations, and, it could also complement the urinary dipstick test in preeclamptic pregnancy.

\section{Funding: No funding sources}

Conflict of interest: None declared

Ethical approval: The study was approved by the Institutional Ethics Committee

\section{REFERENCES}

1. Lim KH, Zhou Y, Janatpour M, McMaster M, Bass K, Chun SH, Fisher SJ. Human cytotrophoblast differentiation/invasion is abnormal in preeclampsia. Am J Pathol. 1997;151:1809.

2. Snydal S. Major changes in diagnosis and management of preeclampsia. J Midwifery Women's Health. 2014;59:596-605.

3. Waller K, Ward KM, Mahan JD, Wismatt D. Current concepts in proteinuria. Clinical Chem. 1989;35:75565.

4. Khowaja AR, Mitton C, Bryan S, Magee LA, Bhutta ZA, von Dadelszen P. Economic evaluation of Community Level Interventions for Pre-eclampsia (CLIP) in South Asian and African countries: a study protocol. Implementation Sci. 2015;10:76.

5. Sibai B, Dekker G, Kupferminc M. Pre-eclampsia. Lancet. 2005;365:785-99.

6. Gruenwald P. Growth of the human fetus: II. Abnormal growth in twins and infants of mothers with diabetes, hypertension, or isoimmunization. Am J Obstet Gynecol. 1966;94:1120-32.
7. Park JH, Chung D, Cho HY, Kim YH, Son GH, Park YW et al. Random urine protein/creatinine ratio readily predicts proteinuria in preeclampsia. Obstet Gynecol Sci. 2013;56:8-14.

8. Shreya G, Pranathi L, Kavitha V. Comparison of spot urine protein-creatinine ratio with 24-hour urine protein excretion in women with preeclampsia. Int $\mathbf{J}$ Intg Med Sci. 2015;2:55-9.

9. Hladunewich M, Karumanchi SA, Lafayette R. Pathophysiology of the clinical manifestations of preeclampsia. Clin J Am Soc Nephrol. 2007;2:543-9.

10. Moser M. Working group report on high blood pressure in pregnancy. J Clin Hypertension. 2001;3:75-88.

11. Schaub S, Rush D, Wilkins J, Gibson IW, Weiler T, Sangster K et al. Proteomic-based detection of urine proteins associated with acute renal allograft rejection. J Am Soc Nephrol. 2004;15:219-27.

12. Rodriguez-Thompson D, Lieberman ES. Use of a random urinary protein-to-creatinine ratio for the diagnosis of significant proteinuria during pregnancy. Am J Obstet Gynecol. 2001;185:808-11.

13. Shahbazian N, Hosseini AF. A comparison of spot urine protein-creatinine ratio with 24-hour urine protein excretion in women with preeclampsia. Iran J Kidney Dis. 2008 Jul;2(3):127-31.

14. Côté AM, Brown MA, Lam E, von Dadelszen P, Firoz T, Liston RM. Diagnostic accuracy of urinary spot protein: creatinine ratio for proteinuria in hypertensive pregnant women: systematic review. BMJ. 2008;336:1003-6.

Cite this article as: Bhadarka N, Poddar K, Joshi S.

Utilization of urine protein/creatinine ratio in pregnancy for diagnosis of preeclampsia. Int J Reprod Contracept Obstet Gynecol 2018;7:3646-8. 